\title{
3 POLITICAL INSTABILITY AND TOURISM IN \\ GHANA (1966-1981)
}

\author{
Opare-Addo Felix Yobo
}

\begin{abstract}
In the 1960s most governments in West Africa, including Ghana which was under the leadership of Dr. Kwame Nkrumah, the first president of Ghana began to incorporate tourism into their economic development plans. The idea was to diversify the economy in order to provide infrastructural development, economic and social prosperity for populace. Unfortunately, Nkrumah's government was toppled in 1966. In the subsequent years, Ghana experienced a period of political instability. This paper takes a critical look at the efforts of the various governments in Ghana (from 1957 to 1981) to develop tourism in terms of their policies and their roles as agents of tourism development; the creation of a conducive environment for tourism to flourish, the involvement of the private sector both foreign and local, the provision of tourism infrastructure and how political instability impacted negatively on tourism development in terms of the flow of international tourist arrivals, potential investors, tourism product development and delivery, and tourism receptive facilities.
\end{abstract}

Keywords: political instability, coup d'état, tourism development, Ghana

\section{INTRODUCTION}

In the history of Ghana, the period 1966-81 could be referred to as the most turbulent years because the country experienced a period of political instability of great magnitude. Within fifteen years, there were seven changes in government. After the heady days of the Convention Peoples Party in 1966, the military government of the National Liberation Council took the reins of government in Ghana. This government lasted three years and handed over power to the Progress Party under the leadership of K.A. Busia in 1969. Three years later in 1972, the Progress Party was overthrown by the military government of the National Redemption Council (NRC) led by Colonel I. K. Acheampong. The National Redemption Council was reconstituted to become the Supreme Military Council (SMC) in 1976, still led by General I. K. Acheampong. In 1978 a palace coup d'état led by General F.W.K. Akuffo overthrew the Supreme Military Council and formed the Supreme Cherith School, Accra, Email: opareaddoyobo@yahoo.com
Military Council II (SMC II). In June 1979 the Supreme Military Council II was overthrown by Flight Lieutenant J. J. Rawlings who formed the Armed Forces Revolutionary Council (AFRC). Flt. Lt Rawlings handed the reins of government to Dr. Hilla Limann led government of Peoples National Party (PNP) after general elections in 1979. Flt. Lt. Rawlings came back in 1981 to overthrow Limann's government and formed the Provisional National Defense Council (PNDC). These short-lived and frequent changes of governments had an adverse impact on tourism development in Ghana.

In Ghana, politics and tourism are so intertwined that political circumstances tend to shape the fortunes of the tourism industry (Wyllie, 2001). This paper argues that tourism development in Ghana has always depended on the general processes of development. Although tourism development should be seen as sectoral, it depended on the general level of 
economic development of the country and such economic development depended on the plans and policies of various governments, for instance, the provision of infrastructure like energy, airport, water, harbour and roads. According to Opare-Addo (2018, p. 41) "The provision of infrastructure alone is crucial for the development of tourism. It forms the basis of tourism development without which tourism cannot thrive or be realized as an economic activity". Such infrastructural development is incumbent on government because such projects are so huge and costly that individuals and private organizations cannot afford. Besides the provision of infrastructure, Governments involvement in the tourism industry has been in a variety of ways, most notably, through national tourism organizations like the Ghana Tourist Board, the Ministry Tourism, and through policies.

The political instability created by frequent changes of government had a negative impact on tourism development in Ghana. During the period of political instability, the various governments could not initiate and formulate economic policies and those who were not able to implement these policies because they were short-lived (Ofosu-Yeboah 2003). Indeed most studies would agree that political instability would discourage tourism industry, the extent of discouragement has not been analyzed in Ghana. In order to fill this gap, analysis is made on how frequent changes of governments affected tourism development including the loss of consistency in implementing tourism policies, investment in tourism and declines in international tourism.

There is considerable literature on political instability and its impact on tourism development. According to Ankomah and Crompton (1990 p.19 as cited in Ryu, 2010) "a major consideration in a potential traveller's decision to visit any foreign destination is that conditions. Any evidence of domestic turmoil is likely to result in a decision not to visit that country". However, there are different forms of political situations and different writers have written on the subject (Anson, 1999; Askjellund, 2003; Butler \& Suntilkul, 2013; Yap \& Saha, 2013; Saha \& Yap, 2014; Teye, 1988).

Neumayer (2004) indicates that political instability, conflict, human rights violation, and violent events lead to a drop in tourist arrivals. This fact (drop in tourist arrivals) is supported by Llorca-Vivero (2008) after he investigated over 130 tourist destinations and concluded that travellers will avoid areas with poor political attributes. Ivanov, Gavrilina, Webster, and Vladyslav (2016) posit political instability leads to negative impact on the tourism industry of a countrydecreased revenues, plummeting numbers of tourists and overnights, and increased costs. Yap and Saha (2013) states political instability reduces tourism demand even in UNESCO listed heritage destinations. To sum the negative effects of political instability on tourism development Clements and Georgiou, 1998; Hall, 1994; Seekings, 1993 as cited in (Issa and Levent, 2006) states that among the difficulties that politically unstable countries face are problems with cash flow, funding and supply, foreign investors, perceptions about hostility, unstable demand, public image, quality of infrastructure, and safety and security issue.

This paper aims to examine the impact of political instability on Ghana's tourism development. The paper has two parts. The first part discusses the efforts made by the various governments towards tourism development since independence in 1957 while the second part provides an analysis of the impact of political instability in Ghana and its consequence on international tourist arrivals.

\section{METHODS}

Both qualitative and quantitative methods were adopted for the study. Data were collected from both 
primary and secondary sources and analysis was done using descriptive analysis and summary statistics. To gather data from primary sources, questionnaires and structured interviews were conducted. Respondents for the survey included public officials from Ghana Tourist Board, Ministry of Tourism, hoteliers, restaurant operators and travel and tour operators in Accra. Oral interviews were also conducted. This involved officials of the Ghana Museums and Monuments Board, Wildlife Division of the Forestry Commission, Centre for National Culture, National Commission on Culture, Ghana Tourist Board and tourism consultants. Archives (PRAAD ADM 5/4/191 and ADM 5/181) provided information on the Volta River Project (Lake Volta, Dodi Island and Akosombo) and (PRAAD ADM 5/3/168 provided information on the Black Star Line. Secondary data sources included final draft on wildlife which provided information on wildlife, Report of Obuam Committee provided information on 1972 tourism feasibility study, magazines (Ghana Airways News Bulletin and Brief history of Ghana Airways contained information on Ghana Airways, and research articles in journals.

\section{CONTRIBUTIONS OF DIFFERENT REGIMES TO TOURISM DEVELOPMENT}

\section{The Convention Peoples' Party (1957-1966)}

The Convention Peoples' Party Government laid the foundation for the development of tourism in Ghana. In connection with tourism, the government passed Executive Instrument No. 121 in 1959, which established the Ghana Tourist Board (Teye, 1988). In 1962, the State Hotels and Tourist Corporation was established (Asiedu, 1997). This was established to develop and manage hotels and other tourist facilities. The State Hotels and Tourist Corporation was split into the State Hotels Corporation (SHC) and the State
Tourist Corporation (STC) by Legislative Instrument 403 of 1965(Asiedu, 1997). The SHC was charged with the building and development of state hotels across the country while the State Tourist Corporation was tasked with the regulation of the hotels and other tourist facilities. Among the objectives of SHC were: first, to undertake all or any of the businesses of proprietors and keepers of hotels, restaurants, cafes, motels, rest houses, beer houses and refreshment rooms. Second, it was to provide for a sufficient number of hotels, motels and similar places of lodging in all the important centres in the Republic and to ensure decent, healthy and hygienic conditions and atmosphere in such places (Opare-Addo 2018). Finally, it was to maintain a close liaison with the STC and any other body with functions similar to those of the said corporation with the view to ensuring the adequacy of accommodation for tourists, travellers and excursionists from both within and outside Ghana (Asiedu, 1997). The State Hotels Corporation, therefore, managed seven deluxe hotels in the country during the period. Four of these hotels were Ambassador, Continental and Star in Accra and the Meridian in Tema. The other three were in other parts of the country. These were Atlantic Hotel in Takoradi, City Hotel in Kumasi and Eredec in Koforidua. By 1957, a few privatelyowned hotels had been licensed and operating in Accra. These hotels were Seaview, located on the High Street, Aams, located on the Accra-Nsawam Road, Avenida on Boundary Road, Lisbon at Airport, Ringway at Kokomlemle on the Ringroad (Handbook of Commerce, 1988). The Government accorded tourism a ministerial position when it was made part of the Ministry of Parks and Gardens. This was a major step by the government to recognize tourism development in Ghana. The Ministry was charged to oversee the development of tourism and the beautification of the country by taking care of parks and gardens, including the Aburi Botanical 
Gardens. The Department of Parks and Gardens was established in 1961 through the enactment of the local government Act 54. The CPP Government provided infrastructure and; established institutions and organizations that saw to the development of the tourism industry. One of these infrastructures was the provision of electricity through the initiation of the Volta River Project. The project provided the Akosombo, Kpong and Bui dams. Akosombo alone was to provide twenty-two times the total capacity of Ghana's electricity requirement in 1958-59. The total installed capacity of electricity in 1957 was 29,907 kilowatts and in 1958-59 the total capacity was 34,336 kilowatts (PRAAD, 1961). The project included the full development of two townships. The Volta River project resulted in the building of the Lake Volta, Dodi Island and Akosombo, which are essentially tourist attractions.

Moreover, the establishment of the Museums and Monument Board by the Nkrumah led CPP government aided the development of the tourism industry. Among the objectives for its establishment were; to conserve and preserve antiquities and historical objects, provide maintenance for forts, castles as well as monuments in the country. The Government established the Ghana Institute of Art and Culture which had the objectives of promoting and developing the arts, culture, disseminating information and supervising the arts including music, drama, art and craft. This was necessary for tourism development because the country's customs, festivals and songs were to be preserved. The Government gave the Institute a legal backing through Executive Instrument 292 of 1962 which established the Arts Council of Ghana. The CPP Government renovated the Accra Airport, which was an airstrip and brought it to the standard of an international airport. The Government also constructed and completed the Tema Harbour in 1962, where ships docked. Tema Motorway, a first-class road and a railway were constructed at Tema. These activities of the Government, undoubtedly, improved transportation within the country, subsequently improving and enhancing tourism activities. Again, in relation to tourism, the CPP Government passed the Wild Animals Preservation Act 43 of 1961. This Act was to consolidate and amend the law relating to wild animals, birds, fish and to continue the observance of the London Convention signed in London on the 19th May 1900. Among the objectives were the protection of certain species of animals, the establishment of reserves as well as the protection and preservation of animals. Indeed, this act created the opportunity for the establishment of game and wildlife reserves.

Act 44 of 1961 established the Municipal Transport Authority. Act 283 of 1963 dissolved the Municipal Transport Authority and formed the National Omnibus Services Authority which asked Councils with respect to their administrative areas to take over the control, management and operation of the omnibus transport undertakings of the authority. "Council" was explained as an administrative area within the meaning of local Government Act 54 of 1961. Also Legislative Instrument 414 of 1964, established the State Transport Corporation to transport passengers and freight within cities or from one place to another within a town. These two Acts were to take care of the transportation needs of the country. Another contribution to the tourism industry by the CPP Government was the creation of Ghana Airways, a wholly-owned Ghanaian airline. On the 15th July 1958, Nkrumah inaugurated the Ghana Airways Corporation with a flight from Accra to London using a leased aircraft and within three years, Ghana Airways had acquired its own fleet of twenty aircraft (Ghana Airways News Bulletin, 1998). By Act 181, Ghana Airways became a corporation on 7th May 1963 and in September of that same year became a member of the International Air Transport Association 
(IATA). The creation of Ghana Airways improved international travel and tourism. This made it possible for tourists from both the sub-region and the rest of the world to easily connect a direct flight to Ghana, especially with the introduction of flights to other parts of Africa and to London. The government also established Ghanaian Consulates abroad where tourists could obtain information about Ghana and also obtain visas. All these institutions, undoubtedly, aided tourism's development in Ghana.

Indeed the government passed Act 160, also known as Alien Act of 1963. It was an act to consolidate with modifications, enactments relating to the immigration, residence, employment and deportation of aliens. This Act spelt out entry requirements for visitors. The CPP Government also established the Black Star Line, which provided a shipping fleet for transportation and haulage. It was initially registered in Ghana in 1957 as a limited liability company jointly owned by the government of Ghana and Zim Israel Navigation Company Limited with a capital of $£ 500,000$ of which the Ghana Government and Zim subscribed 60 and 40\% respectively. By 1965, fourteen new vessels were acquired and these vessels were named after Rivers in Ghana, for instance, Pra, Offin, Birim and Afram. This fleet of ships improved international transport and enhanced Ghana’s image (Opare-Addo, 2018).

\section{The National Liberation Council (1966-1969)}

The first civilian government of Ghana had been overthrown through a coup d'etat in 1966 due to its socialist ideology and for taking the country through a one-party system. The new military regime, the NLC led by Brigadier A.A. Afrifa was pre-occupied with reversing the socialist ideology of the previous government. Actually, the government of the N.L.C. was committed to handing over power to a civilian government and therefore could not formulate any economic policy, let alone a tourism policy throughout its three-year reign. In the words of (Killick, 1978 p.54), the N.L.C. government "was not much concerned with the elaboration of a coherent body of economic ideas. Throughout, it saw itself as a transitional government and adhered with remarkable consistency to its stated intention to hand over power back to an elected civilian government" (Teye 1988 p. 346). The Government was indifferent to tourism and therefore did not take tourism seriously as part of its overall plans for economic development.

However, the N.L.C. government passed the N.L.C decree 310, which changed the Ghana Tourist Corporation to the National Tourist Corporation in 1968. The National Tourist Corporation was "to determine policies relating to development and promotion of tourism and to serve as the central coordinating and advisory board in all matters relating to tourism" (Teye 1988 p 344). Also, to make the Arts Council of Ghana more efficient, the NLC rescinded Executive Instrument 292 and passed NLC Decree 232 of 1968 which established the Arts Council of Ghana. The Council was to promote and encourage appreciation of the arts and in particular preserve, foster and develop the traditional arts and culture of Ghana. In discharging its duty, the Council was to establish, maintain and manage a National Theatre, a National Symphony Orchestra and Choir, a National Art and Craft Gallery, a Dance Ensemble and the Cultural Centres in each of the regions of Ghana and encourage each centre to develop a distinctive bias in arts and crafts. It was also to arrange festivals of arts, arrange for exhibitions of the arts of Ghana to be held in Ghana and other countries, assist Ghanaian artists to visit other countries and induce renowned artists from other countries to visit Ghana, publish a cultural journal at least once in every three 
months and carry out any other functions, including procedural functions, for effectively carrying out the provisions of this Decree. Another attempt made by the N.L.C. in developing tourism was the passing of the N.L.C. Decree 387 of 1969, an Act which backed the establishment of the Ghana Museums and Monuments Board. Although Dr. Nkrumah established the Board in 1957 he did not back it with a legislative instrument. This responsibility was discharged by the military regime of the N.L.C.

\section{The Progress Party (1969-1972)}

The Progress Party (PP) led by Dr. K.A. Busia won the general elections conducted by the N.L.C. In October 1969, Ghana's second republican government was instituted. This government also failed to formulate any policy on tourism. The PP prepared a temporary development plan for 1970/71 fiscal year to guide public sector investment and a five-year development plan (1970-1975). However, the government did not implement these plans before it was overthrown through a coup d'etat in 1972. Within a year of assumption of office, the PP Government passed Act 349 of 1970 which changed the National Tourist Corporation to Ghana Tourist Corporation.

The P.P. Government also amended the Wildlife Regulation Act by passing Legislative Instrument 710 in 1971, which created wildlife reserves like the Mole, Digya and Bui National Parks, Shai Hills Game Reserve, Kogyae Strict Nature Reserve and Owanbi Wildlife Sanctuary. Legal Instrument 651 in 1970 was published to provide, in detail, how the affairs of the national airline, Ghana Airways Corporation should be conducted. According to this instrument, the objectives of Ghana Airways Corporation were to establish, operate and maintain airlines or regular services of aircraft of all kinds, both in Ghana and abroad in an efficient and profitable manner and to carry on the business of transporting mail, passengers and goods, by the Corporation's own aircraft or by other aircraft. Article 24 of the Instrument is particularly interesting because it emphasized the power of the Minister to give directives on matters of policy to the airline.

\section{The National Redemption Council (1972-1976)}

The military Government of the NRC overthrew the PP Government through a coup d'etat in January 1972. The NRC upon assumption of power did not immediately formulate any economic development plan "but rather announced its intention to introduce policies as and when the need should arise" (Teye, 1988 $\mathrm{p}$ 347). Shortly after the assumption of power, the N.R.C. through the Ghana Tourist Corporation undertook an identification and feasibility study on Ghana's tourist attractions and laid on a five-year development plan (1972-76 ) for the development of these tourist attractions. This report known as the Obuam Committee Report, was published in May 1972.

The Government's intention in publishing the report was to incite public interest and invite entrepreneurs to come forward and partner the government to develop these recreational facilities. The importance of tourism in terms of its contribution to the balance of payments, employment and economic growth, in general, was discussed in the government's policy paper. It was also considered that besides being a foreign exchange earner, a viable tourist trade would stimulate investments in transportation, accommodation and food industries. The Obuam Report outlined the policy of the government and these were: the type of tourism to be promoted, the development of tourist attractions in Ghana, the promotion of tourism to ensure a steady inflow of tourists, encouraging maximum performance by the tourist industry, the realization of full benefits from tourism, land use, training and 
assistance, research, the organization and management of tourism and investment policy.

In short, the report highlighted the potential areas for tourism investments and tax concessions and other incentives for potential investors. The government conceded that the realization of these policy objectives required short-term and long-term plans. In 1973, by N.R.C.D 224, the Ghana Tourist Corporation was split into the Ghana Tourism Control Board GTCB) and the Ghana Tourist Development Corporation (GTDC). While GTCB was responsible for defining the overall development goals of the industry, the GTDC was charged with the responsibility of providing financing mechanisms for potential developers in the industry. Among the functions of the G.T.D.C were to: promote and mobilize resources for investment in tourism undertakings or activities, take over the existing commercial operations of the Ghana Tourist Board such as coaches and casinos, seek equity participation in joint ventures with Ghanaians as well as foreign businesses and industries in tourism development and promotion; and promote financial and technical assistance for small scale businesses and to improve the efficiency at all levels of their services.

To further show the commitment of the military regime to develop the tourism industry in the country, the N.R.C. formally requested Danish financial and technical assistance to prepare a feasibility study and a Tourism Master Plan in May 1973. A Danish team of four tourism experts visited every part of the country and logged 8,700 miles by road. Areas that were not accessible by road were covered by plane, helicopter, or boat. The team also visited the West African countries of Senegal, Gambia, Togo and Ivory Coast as well as Kenya and Tanzania in East Africa. The Tourism Master Plan focused on primary development of coastal tourism that is the development of beach resorts, the numerous forts and castles dotted along the coast of Ghana. It also focused on the creation of island resorts on Lake Volta, the development of game parks and the institution of local and overseas training programmes for workers of the industry (Wyllie, 2000).

The Tourism Master Plan was intended to guide tourism planning from 1975-90. The scope of the agreement covered three areas: the first objective was to assess Ghana's tourist assets and facilities in order to increase the occupancy rates of existing hotels with group tourists arriving by air for vacation and international meetings. The second objective was to assess manpower development needs for the hotel sector and tourism organizations such as the Ghana Tourist Board and the Ghana Tourism Development Company. Local and foreign training programmes, possibly through Ghanaian and foreign scholarships were considered. Thirdly, a comprehensive evaluation of the potential for developing the physical, cultural and historical tourism resources of the country was carried out. This included delineation of general and tourismspecific infrastructure needs as well as market segmentation analysis. The final document was presented to the Ghanaian government in April 1974. Unfortunately, these laudable documents; the Obuam Report and the Tourism Master Plan were not implemented. These laudable plans were not implemented for two reasons- The National Tourism Organization lacked autonomy and coordinating guidelines. According to Teye, (1988 p. 345) “Act 349 and NRCD 224 both gave the National Tourism Organization (NTO) a mandate to coordinate tourism development between a multiplicity of organizations like ministries of trade and tourism, information, arts and culture, finance and economic planning, state hotels corporation and bank of Ghana whose activities impinge upon tourism to varying degrees ....and the absence of 
specific coordinating guidelines" It was for these reasons that Plannungs Und Bungesellschaft fur Internationale Touristik of Germany withdrew from building a resort village at Ada in 1974. The resort was to be part of the Master plan tourist region. The N.R.C. also passed Legislative Instruments 881 of 1974, which established the Bia National Park and 1022, which also established the Bomfobiri Wildlife Sanctuary, the Kalakpa and the Gbele Game Reserves.

\section{The Supreme Military Council (1978-1979)}

The N.R.C. Government was reconstituted in 1976 to become the Supreme Military

Council (SMC). This government passed Legislative instrument 1085 of 1976, which established the NiniSuhien National Park in the Nzima-Evalue-JomoroOwira District of the Western Region, the Ankasa Game Reserve in the same Region, the Bia West and Bia South Game Reserves. Again, the SMC Government passed the SMC Decree 80 in 1977, which amended the NRC Decree 224 and changed the Ghana Tourist Control Board to the Ghana Tourism Board. The primary functions of the G.T.B. were to formulate tourism policy, regulate and control the tourism industry, act as government main advisor on promotion and marketing, liaise with National and Regional development agencies in the planning and implementation of tourism programmes within the overall national tourism development framework, to research into and commission studies on trends and other aspects of the industry and to act on any other matters affecting tourism from time to time specify.

Concerning the National Airline, on 6th January 1977, a further Instrument (L.I. 1102) gave the Chief Executive of Ghana Airways, the authority to engage Consultants and Advisors and to appoint a Chief Internal Auditor. Consultants and Advisors were to be engaged to delve into the operation and management of the airline to find inefficiencies anytime the airline ran into a problem and to suggest ways of improving the operations and management of the airline. The Chief Internal Auditor was charged to assist in regularizing the monetary affairs of the corporation. These changes were envisaged to improve the efficient running of the national airline.

\section{The Supreme Military Council II (1978-1979)}

Through a palace coup d'etat the S.M.C. Government was overthrown in 1978. The new government led by General F.W.K. Akuffo became S.MC.II. This regime, unfortunately, did not contribute o tourism's development because it was short-lived. The government lasted only a year and was overthrown by the Armed Forces Revolutionary Council Government in 1979.

\section{The Armed Forces Revolutionary Council (1979)}

The aim of the AFRC Government led by Flt. Lt. J. J. Rawlings was 'house cleaning exercise' due to perceived corruption of members of governments of the N.R.C, S.M.C. and SMC II. The government was committed to the house cleaning exercise so did not formulate any tourism policy. Once, the Government completed the 'exercise' within three months power was handed over to the civilian government of the People's National Party in 1979.

\section{The Peoples' National Party (1979-1981)}

The PNP was in government for two years. The Government did not formulate and implement a tourism policy because it was also short-lived. In 1981, the Government was overthrown once again by Flt. Lt. J.J. Rawlings. He formed the Provisional National Defense Council. 
THE IMPACT OF POLITICAL INSTABILITY ON TOURISM

Political instability of this magnitude had a number of adverse consequences for Ghanaian tourism: first, it discouraged potential visitors by making Ghana seem a highly dangerous and unpredictable part of the world; second, the governments of many foreign countries issued warnings to their citizens who might be contemplating travel to Ghana; third, as Adu-Febiri (1994) acknowledges, it discouraged potential investors from participating in the country's development projects; and fourth, it rendered virtually impossible the continuous, systematic planning and implementation of a national tourism policy. At the same time, the various regimes often differed greatly in their relations with Western societies: some were friendly, others neutral, and others, for instance, the Rawlings' regime (PNDC) stridently hostile to the United States and a number of Western European countries.

The frequent changes in government through coups d'etat during this period, undoubtedly, had adverse consequences on tourism development in Ghana. One of the immediate measures adopted by leaders of a successful coup or by the government in power (in the case of an abortive coup) was to close all land, air and sea borders. Border closures meant that international visitors already in travel status by air could not enter the country. Again, visitors in the country might become stranded until the borders were reopened. During such periods of coups d'etat, permanent roadblocks along major roads, thorough searches of individuals and luggage were so frustrating that they tended to discourage travels.

Another adverse consequence of political instability was that it discouraged potential investors both local and foreign from participating in the country's tourism development projects. A major preoccupation of new military governments was the establishment of commissions of inquiry to investigate, not only assets of selected individuals, but also contracts awarded to local and multinational companies. In such situations, tourism-related development projects were cancelled or suspended. An example of this situation was when in 1981, the Military Government claimed to have been asked by Ghanaians "...to review urgently, all Ghana's agreements with the multinational corporations and abrogate the existing investment code which, they said, had opened the country to rape" (Teye. 1988) Assets of individuals and multinational companies were therefore confiscated. Foreign investors found the economic environment hostile due to attitudes of other governments. For instance, the NRC Government in 1972 refused to honour Ghana's foreign debt obligations. Though this decision was later rescinded, external investors lost confidence in the country.

Political instability rendered virtually impossible the continuous, systematic planning and implementation of a national tourism policy. Between 1972 and 1978, several important studies were undertaken on various aspects of Ghana's tourist industry with foreign assistance- These studies are depicted in table 1 below. These studies were not implemented due to frequent changes of government. A major drawback of the country's tourism development due to political instability was that it made it difficult for Ghana to develop an effective and efficient NTO to coordinate, synthesize and implement the various plans. Two years after independence, the Ghana Tourist Board was established, only to be replaced in 1964 by the State Tourist Corporation. In 1968 the National Tourist Corporation was created as the central advisory board with responsibility for formulating tourism policy and for promoting tourism development. In 1970 the Ghana Tourist Corporation was created but this was replaced 
later by the Ghana Tourist Control Board in 1973. These short-lived national tourism organizations muddled along with weak mandates and inadequate resources. In a developing country like Ghana, public initiative is crucial for the coordination and implementation of tourism policy and planning, therefore the chaotic situation just outlined proved to be a major handicap.

Table 1 Selected Documents on Tourism development in Ghana

\begin{tabular}{|c|c|c|c|c|}
\hline Year & Focus & Title & Sponsor & Type of Government \\
\hline 1972 & Resource Inventory & $\begin{array}{l}\text { Report of the feasibility study } \\
\text { committee on the development of } \\
\text { Ghana's Tourist Attraction for } \\
\text { the Five Year Plan Period 1972- } \\
76\end{array}$ & Government of Ghana & Civilian \\
\hline 1973 & $\begin{array}{l}\text { Planning and } \\
\text { Development }\end{array}$ & Tourism in Ghana & $\begin{array}{l}\text { Government of Ghana / } \\
\text { UNDP }\end{array}$ & Military \\
\hline 1973 & Development & $\begin{array}{l}\text { Developing the Tourist Industry } \\
\text { of Ghana }\end{array}$ & $\begin{array}{l}\text { Government of Ghana / } \\
\text { USAID }\end{array}$ & Military \\
\hline 1973 & Economic Impact & $\begin{array}{l}\text { Tourism and Foreign Exchange } \\
\text { Earnings in Ghana }\end{array}$ & ISSER & Military \\
\hline 1974 & Tourism Master Plan & $\begin{array}{l}\text { Tourism in Ghana Development } \\
\text { Guide }\end{array}$ & $\begin{array}{l}\text { Government of Ghana / } \\
\text { DANIDA }\end{array}$ & Military \\
\hline 1975 & Resource Utilization & $\begin{array}{l}\text { Tourism in Ghana utilizing } \\
\text { present resources }\end{array}$ & $\begin{array}{l}\text { Ghana Tourist Board / } \\
\text { International Executive } \\
\text { Corps }\end{array}$ & Military \\
\hline 1975 & Economic Impact & $\begin{array}{l}\text { The Tourist Multiplier } \\
\text { Expenditure in Ghana }\end{array}$ & $\begin{array}{l}\text { Ghana Tourist Control } \\
\text { Board }\end{array}$ & Military \\
\hline 1976 & Social Impact & $\begin{array}{l}\text { The Impact of Tourism on Social } \\
\text { Life in Ghana }\end{array}$ & $\begin{array}{l}\text { Government of Ghana/ } \\
\text { ISSER }\end{array}$ & Military \\
\hline 1978 & $\begin{array}{l}\text { Manpower } \\
\text { Development of } \\
\text { Ghana's Tourist } \\
\text { Industry }\end{array}$ & $\begin{array}{l}\text { Manpower and Training } \\
\text { Requirements }\end{array}$ & $\begin{array}{l}\text { Government of Ghana / } \\
\text { UNDP }\end{array}$ & Military \\
\hline
\end{tabular}

Source: (Teye, 1988)

Further impact of political instability was that tourism reception and handling facilities were also neglected. Obtaining visas for a visit to Ghana was usually a time-consuming business. There was no electronic screening equipment at the Kotoka International Airport so that visitors had to cope with long queues, intimidating immigration and customs personnel and an army of hustlers posing as accredited airport officials. Visitors arriving at the airport were made to go through the ordeal of body and luggage searches. During political crises, it was common to find armed soldiers barking orders at jet-lagged visitors. Visitors were also required to report to the Ministry of Interior within twenty-four hours of arrival and to 
relinquish their passports to the Chief Immigration Officer two days before departure in order to obtain the necessary exit permits (Wyllie 2000). The results of years of government neglect were also apparent in a lack of skilled tourism manpower, poor entrepreneurial attitudes, outdated office systems and equipment and the absence of a competitive marketing strategy by local operators. In the accommodation sector of the tourism industry, there was a shortage of hotels suitably located and designed to cater to leisure travellers. As a result of the frequent changes and its negative effect on tourism, international tourist arrivals dwindled. Table 2 depicts the yearly international tourist arrivals.

Table 2 Ghana's International Tourist Arrivals (1972-1981)

\begin{tabular}{ll}
\hline Year & Tourist Arrivals \\
\hline 1972 & 62,381 \\
1973 & 53,039 \\
1974 & 30,151 \\
1975 & 43,904 \\
1976 & 55,834 \\
1977 & 58,988 \\
1978 & 46,253 \\
1979 & 37,450 \\
1980 & 39,574 \\
1981 & 35,396 \\
\hline
\end{tabular}

Table 2 shows that international tourist arrivals fluctuated during this period. A year after the 1972 military takeover of government by the NRC, international tourist arrival fell by $15 \%$. It fell $43 \%$ further in 1974. It began to rise in 1975 till 1977. The rise was $40 \%, 85 \%$ and $96 \%$ respectively. This rise was attributed to the fact that the military government had established and stabilized itself in government for five years. International tourist arrival fell again in 1978 and
1979. The fall was $22 \%$ and $36 \%$ respectively. The fall was attributed to the military takeover of governments in 1978 by SMC II and in 1979 by AFRC. It rose in 1980 by $6 \%$ and fell again in 1981 by $10 \%$. The rise in 1980 was attributed to the return to civilian rule which created confidence in international tourists to visit the country. However, the fall in 1981 was attributed to the scare of military takeover that engulfed the country. International tourist arrivals that stood at 62,381 in 1972 fell to 35,396 in 1981 , a fall of about $57 \%$.

\section{CONCLUSION}

The CPP Government provided tourism facilities like hotels and guest houses across the length and breadth of the country, and created Ghana Airways. The Government also established institutions like the Ghana Tourist Board, Municipal Transport Authority (later National Omnibus Authority), State Transport Corporation, State Hotels Corporation (now defunct), Black Star Line (also defunct), Museums and Monument Board and Ghana Institute of Arts and Culture. Moreover, the CPP Government provided tourism infrastructures like energy, railways, roads and harbours. For these efforts, one is inclined to accept the notion that the CPP Government contributed immensely to the development of tourism. Due to the activities and leadership role of Kwame Nkrumah in the Pan-African Movement, the country became a magnet for many African-Americans who were on root-seeking journeys and mostly identified strongly with Ghana as the first newly independent African nation, its exciting efforts in nation-building as well as its attempt to develop and practice Scientific Socialism. Though these activities were for the promotion of pan-Africanism, it indirectly promoted arrivals in international tourists in Ghana. As a result, many African-Americans as well as other Africans visited the country as tourists during Nkrumah's era. It was not only Africans and African- 
Americans that visited Ghana but also Europeans especially the British. British colonial administrators, business officials and their descendants as well as other Europeans like the Germans, Danes and Dutch spread good news about Ghana and the government's effort at building a new nation. Unfortunately, statistics are unavailable to support this fact.

In spite good foundation laid by the CPP Government for tourism development, there was no expansion in the development of tourism by subsequent governments. The lack of expansion was due to political instability. The frequent changes and the short-lived nature of the various government made it impossible for the various governments to formulate and implement policies to develop the tourist industry despite the several studies undertaken by these governments, most notably the Tourism Master Plan. The frequent changes of governments rendered the NTO, for instance, the Ghana Tourism Board and the Ministries of Tourism ineffective due to conflicting mandates and directives. As a result, the various governments could not play their roles as agents of tourism development; the creation of a conducive environment for tourism to flourish, the involvement of the private sector both foreign and local and the provision of tourism infrastructure. In lieu, tourist industry stagnated in terms of development and international tourist arrivals during the period of political instability.

A major limitation for this research is the lack of research on the activities of Dr. Nkrumah which indirectly promoted tourism arrivals in Ghana. Subsequently, there is a lack of literature. Therefore, I recommend future investigation into his activities and how these activities promoted tourism arrivals in Ghana. For instance, to what extent did his activities like leadership style, an attempt at nation-building, promotion of pan-Africanism, the practice of scientific socialism, and his relationship with other foreign countries promote tourism arrivals in Ghana?

\section{REFERENCES}

Addo-Yobo E. (2003, February 14). Executive Secretary, Museums and Monuments Board, Accra.

Agbley, Kwasi A. (2003, January 24). President \& Chief Executive, Tourism \& Heritage Consultants, Accra. Keben \& Associates Ltd

Ankomah, P.K. \& Crompton, J.L. (1990). The Unrealized Tourism Potential: The case Study of Sub-Saharan Africa. Tourism management, 11(1), $11-28$

Akwoviah, A. (2004, September 15). Director of Operations, Department of Wildlife, Accra.

Akyeampong, O.A. (1996). Tourism and Regional Development in Sub-Saharan Africa: A Case Study of Ghana's Central Region. Stockholm: University of Stockhom.

Asiedu, A. B. (1997). Prospects for an emerging tourism industry in Ghana. Research Review, 13(1\&2), $11-26$

Attipoe, M. H. (2003, February 11). Director of Finance National Commission On Culture, Accra

Clements M.A \& Georgiou, A. (1998). The impact of political instability on a fragile tourism product. Tourism Management, 19(3), 283-288

Ghana Airways News Bulletin (1998). Celebrating 40 years of Star Service. Accra, Ghana.

Ghana Airways (2004). Brief History of Ghana Airways. Accra, Ghana.

Hall, C.M. (1996). Tourism and Politics: Policy, Power and Place. England: John Wiley \& Sons Ltd

Issa, I. A. and Levent, A. (2006). Impact of political instability on tourism planning and development: The case study of Lebanon. Tourism Economies, 12(3), 361-381. 
Ivanov S., Gavrilina, M., Webster, C., \& Ralko, V. (2017). Impacts of political instability on the tourism industry in Ukraine. Journal of Policy Research in Tourism, Leisure and Events, 9(10, 100-127.

Kodua, P. (2004, August 16). Assistant Manager, Research \& Corporate Planning, Ghana Airways, Accra.

Matey, V. A. (2004 January 14), Senior Curator, Ghana Museums and Monuments Board, Accra.

Ministry of Trade and Tourism. (1988). Handbook of Commerce and Industry, Accra, Venus Printing Press.

Obuam Committee. (1972). Report on Feasibility Committee on the development of Ghana's

Tourist Attractions for the 5 Year Plan Period, 1972-76, Accra, Ghana.

Ofosu-Yeboah, K. (2003 January 22). Former Chief Executive, Ghana Tourist Development Company, Accra.

Opare-Addo, Y. (2018). The Attitudes of the Various Governments Towards Tourism in Ghana: 1957-2000. Lap-Lambert Publications.

PRAAD. (1961, ADM 5/4/191). The Volta River Project: Statement by Government of Ghana. Accra, Government Printer.

PRAAD, Accra, ADM 5/1/181, Volta River Authority Annual Report, 1962.
PRAAD, Accra, ADM 5/3/168, proceedings and Interim Report on operations of the Black Star Line. 1963 Republic of Ghana. (1975). Cultural Policy in Ghana. Accra: Ministry of Education and Culture Republic of Ghana. (1998). Handbook of Commerce and Industry. Accra, Venus Printing Press.

Republic of Ghana. (1961). The Wildlife Animals Preservation Act. Accra: Ghana

Seekings, K. (1993). The Politics of Tourism. London: Prontaprint

Teye, V. B. (1988). Coup D'etat and African Tourism: A Study of Ghana. Annals of Tourism Research, $15,329-356$

Twum, M. (2004, January 14). Senior Research Officer, Ghana Tourist Board: Accra,

Wildlife Department. (1998). Development Plan: 19982003, Final Draft, Volume1, Overview and Summary, Accra.

Wyllie, R. (2000). Tourism and Society: A Guide to problems and Issues. Pennsylvania: Venture Publishing Inc.

Yap, G., and Saha, S. (2013). Do political instability, terrorism, and corruption have deterring effects on tourism development even in the presence of UNESCO heritage? A cross country panel estimate. Tourism Analysis, 18(5), 587-599. 